\title{
Impact of chronic disease on quality of life among the elderly in the state of São Paulo, Brazil: a population-based study
}

\author{
Margareth Guimarães Lima, ${ }^{1}$ Marilisa Berti de Azevedo Barros, ${ }^{1}$ \\ Chester Luiz Galvão César, ${ }^{2}$ Moisés Goldbaum, ${ }^{3}$ \\ Luana Carandina, ${ }^{4}$ and Rozana Mesquita Ciconelli ${ }^{5}$
}

Suggested citation

Lima MG, Barros MBA, César CLG, Goldbaum M, Carandina L, Ciconelli RM. Impact of chronic disease on quality of life among the elderly in the state of São Paulo, Brazil: a population-based study. Rev Panam Salud Publica. 2009;25(4):314-21.

ABSTRACT Objectives. To assess the impact of chronic disease and the number of diseases on the various aspects of health-related quality of life (HRQOL) among the elderly in São Paulo, Brazil. Methods. The SF-36 ${ }^{\circledR}$ Health Survey was used to assess the impact of the most prevalent chronic diseases on HRQOL. A cross-sectional and population-based study was carried out with two-stage stratified cluster sampling. Data were obtained from a multicenter health survey administered through household interviews in several municipalities in the state of São Paulo. The study evaluated seven diseases - arthritis, back-pain, depression/anxiety, diabetes, hypertension, osteoporosis, and stroke - and their effects on quality of life.

Results. Among the 1958 elderly individuals (60 years of age or older), $13.6 \%$ reported not having any of the illnesses, whereas $45.7 \%$ presented three or more chronic conditions. The presence of any of the seven chronic illnesses studied had a significant effect on the scores of nearly all the SF-36 ${ }^{\circledR}$ scales. HRQOL achieved lower scores when related to depression/ anxiety, osteoporosis, and stroke. The higher the number of diseases, the greater the negative effect on the SF-36 ${ }^{\circledR}$ dimensions. The presence of three or more diseases significantly affected $H R Q O L$ in all areas. The bodily pain, general health, and vitality scales were the most affected by diseases.

Conclusions. The study detected a high prevalence of chronic diseases among the elderly population and found that the degree of impact on HRQOL depends on the type of disease. The results highlight the importance of preventing and controlling chronic diseases in order to reduce the number of comorbidities and lessen their impact on HRQOL among the elderly.

Key words Health of the elderly, chronic disease, quality of life, Brazil.

Department of Preventive and Social Medicine, School of Medical Sciences, Universidade Estadual de Campinas, São Paulo, Brazil. Send correspondence to: Margareth Guimarães Lima, Departamento de Medicina Preventiva e Social, Faculdade de Ciências Médicas, Unicamp, Caixa postal 6111, Campinas, SP, 13083-970, Brasil; telephone: +55-19-3521-8042; fax: +55-19-3521-8044; e-mail: margareth.guimaraes@yahoo.com.br

2 Department of Epidemiology, School of Public Health, Universidade de São Paulo, São Paulo, Brazil.
The onset of chronic disease tends to increase with age. Rising life expectancy

3 Department of Preventive Medicine, School of Medicine, Universidade de São Paulo, São Paulo, Brazil.

4 Department of Public Health, Botucatu School of Medicine, Universidade Estadual Paulista, Botucatu, Brazil.

5 Department of Medicine, Universidade Federal de São Paulo, Brazil. leads to a greater number of elderly individuals and a subsequent increase in the prevalence of chronic conditions among the population. In 2003, the Brazilian Household Sampling Survey found that over $70 \%$ of the country's population 60 years of age or more had at least one chronic disease and $25.6 \%$ reported having three or more diseases $(1,2)$. 
Noncommunicable chronic diseases are conditions that tend to stay with individuals for a long period of time. These diseases can present periods of worsening, stabilization, and noticeable improvement, and may affect different organs and systems. Chronic diseases often require prolonged periods of treatment, a fact that places a significant demand on state-funded health care services (3). The demand is even higher when chronic conditions are not properly controlled. Such situations lead to incapacity and limit the independence and quality of life of elderly individuals $(4,5)$.

The impact that disease has on quality of life should be assessed and monitored. This can be achieved through surveys that include measurements of functional capacity and wellbeing $(6,7)$. Instruments that assess health-related quality of life (HRQOL) measure the degree to which functional, physical, mental, and social aspects are impaired by symptoms, incapacities, and limitations caused by diseases $(8,9)$. HRQOL can be measured by either generic or specific instruments that, for the most part, were originally developed in the English language, translated into other languages, and validated for different cultures (10). The SF-36 ${ }^{\circledR}$ (Medical Outcomes Trust, Waltham, Massachusetts, United States) was translated and validated in Brazil by Ciconelli et al. (1999) in a study on individuals with rheumatoid arthritis (11). It was considered to be adequate with regard to the socioeconomic and cultural characteristics of the population studied. There are surveys applying SF-36 ${ }^{\circledR}$ instrument in more than 40 countries that have demonstrated the high reliability and validity of these scales (12). The instrument measures several dimensions of health and assesses the impact of diseases and the benefits of treatment. It is a generic HRQOL instrument composed of 36 items organized into eight health concepts: physical functioning, role-physical, bodily pain, vitality, general health, role-emotional, social functioning, and mental health $(10,11)$.

The objective of the present study was to evaluate the impact of the most prevalent chronic conditions and the number of diseases that an individual reports on quality of life as assessed by the SF- $36^{\circledR}$.

\section{MATERIAL AND METHODS}

A cross-sectional population-based study was developed from data col- lected in a multicenter health survey carried out in the State of São Paulo from 2001-2002 (São Paulo State Health Survey (ISA-SP)).

\section{Sample population}

The following areas were included in the ISA-SP: the cities of Botucatu and Campinas; an area encompassing the cities of Itapecerica da Serra, Embu, and Taboão da Serra; and the District of Butantã, in the city of São Paulo (13). The state of São Paulo is the most populous in the country and has the highest per capita income. The areas studied are somewhat socioeconomically diverse. The area encompassing Itapecerica da Serra, Embu, and Taboão da Serra has the poorest housing, lowest level of education, and lowest income. Botucatu has the best housing conditions. Heads of families have the highest level of school in the District of Butantã and city of Campinas. Despite the differences, all these areas have a standard of living that is higher than the national average (13).

Sampling for ISA-SP was carried out through a two-stage stratified cluster procedure: in the first stage, the sample unit was a census tract; in the second, it was a household. For the census tracts, each of the four areas were organized into three strata, according to the percentage of heads of families with university-level education: less than 5\%,5-25\%, and greater than $25 \%$. Ten census tracts were drawn for each stratum, totaling 120 tracts in the four areas. In the second stage, households were sampled from each census tract.

To maintain satisfactory subpopulation sample sizes, the following gender and age groups were defined: infants less than 1 year of age, children from 1-11 years of age, women from 12-19 years, men from 12-19 years, women from 20-59 years, men from 20-59 years, women of 60 years or more, and men of 60 years or more. In each household sampled, all individuals belonging to the selected gender and age group were interviewed. The minimum sample size was estimated to be 200 individuals from each area for each group. Sample size calculation was obtained using the following formula:

$$
n_{0}=P(1-P) /(d / z)^{2} . \text { deff }
$$

where $P$ is the proportion to be estimated; $z$ is the value in the normal dis- tribution curve of the confidence level; $d$ is the admitted sample error; and deff is the design effect. Considering the following: a 95\% confidence interval $(z=1.96)$; a sample error of $10 \%$ (i.e., that the distance between the sample estimate and the population parameter would not be greater than this value, $d=0.10$ ); that the proportion to be estimated is $50 \%$ $(P=0.50)$, considering that this has the greater variability and leads to a conservative sample size); and, a design effect of 2 (i.e., the amount by which the variance of a estimate derived from a complex sample delineation increases, compared to that produced by a simple random sampling design) $(14,15)$.

Considering the possibility of a $20 \%$ loss, 250 individuals were drawn for each of eight groups (14). The present study only analyzed data from groups of people who were 60 years of age or more, a total of 1958 individuals. All the elderly individuals interviewed in the survey were included in this analysis.

\section{Survey instrument and variables}

Data were collected by means of a precoded questionnaire that was administered directly to the sampled individuals by trained interviewers. The questionnaire was organized into 19 subject areas including the 8 scales of the SF- $36^{\circledR}$. The variables analyzed pertained to two principal topics: health-related quality of life (employing the SF-36 ${ }^{\circledR}$ ) and selfreported chronic diseases (using a checklist). Gender, age, and education were also recorded as demographic and socioeconomic variables.

The dependent variables came from the scores on each of the eight SF-36 ${ }^{\circledR}$ scales: physical functioning, role-physical, bodily pain, vitality, general health, role-emotional, social functioning, and mental health. The methodology proposed for the instrument was used to obtain the scores $(10,11)$. A specific grade was attributed to each item based on the interviewee's response. The points for the questions and items in each of the eight scales were added up. The total scores for each of the eight scales were then converted to points from 0 to 100 , with 0 denoting the worst state of health and 100 denoting the best $(10,11)$.

The following were the independent variables:

- Chronic diseases specified on the checklist (arthritis/rheumatism/ar- 
throsis, back-pain, depression/anxiety, diabetes mellitus, hypertension, osteoporosis, and stroke), divided into categories of either "reporting" or "not reporting" the disease.

- Number of morbidities reported, in five categories: not presenting any morbidity; presenting one; presenting two; presenting three or four; and presenting five or more.

- Demographic and socioeconomic variables: gender (male/female); three age categories: 60-69 years of age, 70-79 years, 80 years or more; and education: $0-3$ years of study; $4-8$; or 9 or more.

Statistical analysis consisted of calculating means, standard deviations, and 95\% confidence intervals for each of the SF-36 ${ }^{\circledR}$ scale scores for each disease. Mean differences were then calculated and tested by Student's t test. Simple linear regression analysis was used to compare the score for each disease to the score of those without the specific disease, though they reported other diseases on the checklist. This was followed with a second regression model that compared individuals with the given disease to those without any of the checklist diseases. In these analyses, one model was performed for each scale and each disease. Linear regression analysis was also used to determine the effect of the number of self-reported diseases on the SF- $36^{\circledR}$ scores. Adjustments were made for gender, age, and schooling (categorical variables) using multiple linear regression models. In all analyses, a $P$ value of less than 0.05 was considered to be statistically significant. Analyses were performed using STATA 8.0 software (StataCorp LP, College Station, Texas, United States), incorporating weightings and taking the clusters and stratification used in the sample design into account.

The present study was approved by the ethics committees of the School of Medical Sciences of the State University of Campinas, Campinas, São Paulo.

\section{RESULTS}

The data analyzed came from a total of 1958 individuals-929 males and 1029 females 60 years of age or more. The mean age of the sample was 69.9 years $(+0.35)$, or $70.1(+0.44)$ years for females and $69.0(+0.40)$ years for males. Females made up a larger percentage of the sample $(57.2 \%)$, and the largest age group was 60-69 years of age (55.8\%). In terms of education, $42.6 \%$ had fewer than four years of schooling and $19 \%$ had nine years or more. Of the total, $80.2 \%$ were Caucasian, $75.5 \%$ were Catholic, $58.9 \%$ lived with a spouse, and $23.4 \%$ had a per capita income less than minimum wage. Of the individuals living at home, $9.4 \%$ were lost, with $9.1 \%$ due to refusals and $0.3 \%$ for other reasons.

Of the chronic diseases included in the study, the most prevalent were hypertension $(51.0 \%)$, back pain $(30.1 \%)$, arthritis/rheumatism/arthrosis (27.2\%), and depression/anxiety (24.5\%) (Table $1)$. The mean number of chronic diseases in this sample was $2.1(+0.04)$. Only $13.6 \%$ of the elderly individuals reported no chronic condition, while $45.7 \%$ reported three or more. The prevalence of chronic conditions was higher among women and in age groups over 70 years. There was no significant difference with regard to schooling in relation to the number of illnesses reported. Analyzing the diseases separately, hypertension was the only disease that was more prevalent among those with less schooling (data not shown).

The crude and adjusted means for the SF- $36^{\circledR}$ scales for those who reported one of the chronic diseases versus those who

TABLE 1. Sample characteristics and prevalence of reported morbidities among $1958 \mathrm{el}-$ derly individuals in the State of São Paulo, Brazil, 2001-2002

\begin{tabular}{|c|c|c|}
\hline Variable & No. & $\%^{a}$ \\
\hline \multicolumn{3}{|l|}{ Gender } \\
\hline Male & 929 & 42.7 \\
\hline Female & 1029 & 57.2 \\
\hline \multicolumn{3}{|l|}{ Age (in years) } \\
\hline $60-69$ & 1092 & 55.8 \\
\hline $70-79$ & 645 & 33.3 \\
\hline 80 or more & 221 & 10.8 \\
\hline \multicolumn{3}{|l|}{$\begin{array}{l}\text { Number of morbidities } \\
\text { (from the study checklist) }\end{array}$} \\
\hline 0 & 274 & 13.6 \\
\hline 1 & 397 & 19.3 \\
\hline 2 & 409 & 21.1 \\
\hline 3 or 4 & 543 & 29.5 \\
\hline 5 or more & 326 & 16.2 \\
\hline \multicolumn{3}{|l|}{ Type of morbidity } \\
\hline Hypertension & 941 & 51.0 \\
\hline Diabetes mellitus & 292 & 15.4 \\
\hline Back pain & 621 & 30.1 \\
\hline Arthritis/rheumatism/arthrosis & 505 & 27.2 \\
\hline Stroke & 93 & 4.5 \\
\hline Depression/anxiety & 476 & 24.5 \\
\hline Osteoporosis & 266 & 14.5 \\
\hline
\end{tabular}

a Weighted percentages considering the sample design. reported none are displayed in Tables 2a and $2 \mathrm{~b}$. For all morbidities in nearly all scales, mean scores adjusted for gender and age were significantly lower among individuals who reported having a disease. The exceptions were the following scales: role-physical and role-emotional for those with diabetes; role-emotional for back-pain; social functioning for stroke; social functioning and role-emotional for osteoporosis; social functioning for arthritis/rheumatism/arthrosis; and role-physical for depression/anxiety.

Table 3 shows the effect of each disease on the score for each SF-36 ${ }^{\circledR}$ scale (through the beta coefficients of the multiple linear regression), comparing the group with a specific disease to those with no chronic conditions (adjusted for age, gender, and schooling, which were included in the regression model). Mean SF-36 ${ }^{\circledR}$ scores were significantly lower for the seven diseases studied.

Quality of life was most impacted among patients reporting a stroke, scoring the lowest on five of the eight SF-36 ${ }^{\circledR}$ scales. Osteoporosis patients had large differences in mean scores, particularly on the bodily pain, role-physical, and physical functioning scales. Depression/ anxiety made a considerable impact as well, with large differences in mean score, particularly affecting mental health and role-emotional. Arthritis and backpain had the greatest effect on the bodily pain domain. Individuals with diabetes achieved the lowest scores on the general health scale, whereas those with hypertension had the lowest scores on the bodily pain and vitality scales.

The least affected SF-36 ${ }^{\circledR}$ scales were role-emotional and social functioning in relation to all morbidities, except for stroke and depression/anxiety. On the other hand, the most affected scales were generally bodily pain, general health, and vitality.

Based on the number of self-reported morbidities (Table 4), mean scores decreased progressively and substantially with a rise in the number of diseases, compared to the scores for individuals with no morbidities. For two chronic conditions, mean scores were significantly lower on all scales, except for role-emotional. For three or more conditions, means were markedly lower on all scales.

The bodily pain and vitality domains were the ones most affected by an increase in the number of morbidities, whereas the smallest reductions oc- 
TABLE 2a. Mean scores and mean differences of SF- $36^{\circledR}$ scales according to the presence or absence of chronic conditions among 1958 elderly individuals in the State of São Paulo, Brazil, 2001-2002

\begin{tabular}{|c|c|c|c|c|}
\hline \multirow[b]{2}{*}{ Scale } & \multicolumn{2}{|c|}{ Mean SF-36 ${ }^{\circledR}$ scores and $95 \% \mathrm{Cl}$} & \multicolumn{2}{|c|}{ Mean differences } \\
\hline & $\begin{array}{c}\text { With } \\
\text { morbidity }\end{array}$ & $\begin{array}{l}\text { Without } \\
\text { morbidity }\end{array}$ & $\begin{array}{c}\text { Unadjusted } \\
\text { ( } P \text { value })\end{array}$ & $\begin{array}{c}\text { Adjusted by } \\
\text { age and gender } \\
(P \text { value })\end{array}$ \\
\hline \multicolumn{5}{|l|}{ Hypertension } \\
\hline Physical functioning & $66.0(62.9-69.1)$ & $77.0(74.5-79.6)$ & $-11.0(0.000)$ & $-9.4(0.000)$ \\
\hline Role-physical & $78.0(73.4-82.6)$ & $84.4(80.8-87.9)$ & $-6.4(0.003)$ & $-5.1(0.011)$ \\
\hline Bodily pain & $70.2(67.4-73.0)$ & $78.3(76.0-80.6)$ & $-8.1(0.000)$ & $-7.2(0.000)$ \\
\hline General health & $66.6(64.8-68.5)$ & $73.6(71.2-76.1)$ & $-7.0(0.000)$ & $-5.8(0.000)$ \\
\hline Vitality & $60.2(57.7-62.7)$ & $68.8(66.2-71.3)$ & $-8.6(0.000)$ & $-7.2(0.000)$ \\
\hline Role-emotional & $83.4(80.4-86.4)$ & $88.9(85.8-92.0)$ & $-5.5(0.008)$ & $-4.2(0.039)$ \\
\hline Social functioning & $83.8(80.4-87.2)$ & $88.1(85.8-90.4)$ & $-4.3(0.006)$ & $-3.9(0.005)$ \\
\hline Mental health & $67.3(65.3-69.3)$ & $72.6(70.2-75.0)$ & $-5.3(0.001)$ & $-4.6(0.004)$ \\
\hline \multicolumn{5}{|l|}{ Diabetes mellitus } \\
\hline Physical functioning & $64.8(60.9-68.7)$ & $72.6(69.9-75.3)$ & $-7.8(0.000)$ & $-8.2(0.000)$ \\
\hline Role-physical & $79.2(73.2-85.1)$ & $81.5(77.7-85.4)$ & $-2.3(0.438)$ & $-2.3(0.404)$ \\
\hline Bodily pain & $70.8(67.1-74.5)$ & $74.8(72.4-77.2)$ & $-4.0(0.052)$ & $-4.0(0.044)$ \\
\hline General health & $63.0(59.4-66.4)$ & 71.4 (69.5-73.2) & $-8.4(0.000)$ & $-8.3(0.000)$ \\
\hline Vitality & $60.0(56.1-64.0)$ & $65.1(63.0-67.3)$ & $-5.1(0.012)$ & $-5.1(0.007)$ \\
\hline Role-emotional & $82.3(75.2-89.4)$ & $86.8(84.2-89.4)$ & $-4.5(0.258)$ & $-4.4(0.248)$ \\
\hline Social functioning & $82.4(77.3-87.1)$ & $86.6(84.0-89.2)$ & $-4.2(0.065)$ & $-4.5(0.049)$ \\
\hline Mental health & $65.9(62.4-69.2)$ & 70.6 (68.9-72.3) & $-4.7(0.015)$ & $-4.6(0.017)$ \\
\hline \multicolumn{5}{|l|}{ Back pain } \\
\hline Physical functioning & $64.7(61.4-67.8)$ & 74.4 (71.6-77.2) & $-9.7(0.000)$ & $-8.9(0.000)$ \\
\hline Role-physical & $74.0(68.5-79.5)$ & $84.3(81.1-87.6)$ & $-10.3(0.000)$ & $-9.6(0.000)$ \\
\hline Bodily pain & $63.8(61.1-66.4)$ & $78.8(76.6-81.0)$ & $-15.0(0.000)$ & $-14.5(0.000)$ \\
\hline General health & $63.3(60.6-66.1)$ & $73.0(71.2-74.9)$ & $-10.3(0.000)$ & $-8.9(0.000)$ \\
\hline Vitality & $58.2(55.1-61.3)$ & $67.1(64.9-69.4)$ & $-8.9(0.000)$ & $-8.0(0.000)$ \\
\hline Role-emotional & $84.0(79.8-87.9)$ & $87.1(84.6-89.5)$ & $-3.1(0.149)$ & $-5.1(0.253)$ \\
\hline Social functioning & $82.3(78.2-86.3)$ & $87.6(85.3-89.8)$ & $-5.3(0.002)$ & $-2.4(0.002)$ \\
\hline Mental health & $66.1(63.8-68.1)$ & 71.7 (69.8-73.5) & $-5.6(0.000)$ & $-5.2(0.000)$ \\
\hline \multicolumn{5}{|l|}{ Stroke } \\
\hline Physical functioning & $49.0(37.8-60.1)$ & $72.3(69.8-74.8)$ & $-23.3(0.000)$ & $-23.1(0.000)$ \\
\hline Role-physical & $56.1(40.7-71.5)$ & $82.2(78.6-85.8)$ & $-26.1(0.001)$ & $-25.6(0.001)$ \\
\hline Bodily pain & $64.8(56.4-73.1)$ & $74.6(72.4-76.8)$ & $-9.8(0.019)$ & $-10.0(0.017)$ \\
\hline General health & $54.9(46.6-63.0)$ & 70.7 (69.0-72.3) & $-15.8(0.000)$ & $-15.8(0.000)$ \\
\hline Vitality & $55.3(47.5-63.7)$ & $64.7(62.9-66.8)$ & $-9.4(0.023)$ & $-8.9(0.022)$ \\
\hline Role-emotional & $68.1(54.1-82.1)$ & $86.8(84.5-89.1)$ & $-18.7(0.008)$ & $-18.5(0.008)$ \\
\hline Social functioning & 77.9 (68.4-87.2) & $86.3(83.7-88.8)$ & $-8.4(0.078)$ & $-8.6(0.070)$ \\
\hline Mental health & $58.4(52.7-63.9)$ & $70.3(68.7-71.9)$ & $-11.9(0.000)$ & $-12.2(0.000)$ \\
\hline
\end{tabular}

curred in the role-emotional and social functioning scales.

\section{DISCUSSION}

This was the first population-based study in Brazil to measure the impact of chronic diseases using the SF-36 ${ }^{\circledR}$ survey. In Brazil, the impact of disease on HRQOL has generally been limited to specific diseases and either outpatients or inpatients (16-19). Studies carried out in other countries have provided information on the effect of specific diseases on the areas assessed by SF-36 ${ }^{\circledR}(20,21)$; however, few studies have assessed and compared the impact of various different morbidities on HRQOL $(22,23)$. Alonso condition), was greater than what has been recorded among the elderly in Brazil as a whole (78\%) (2). The present study also showed that $45.7 \%$ had three or more chronic conditions, while the rate for the Brazilian elderly population has been described as $25.6 \%$ (2). Since the study population was at a higher socioeconomic level than the average Brazilian, the higher prevalence of disease is probably due to better access to health services and a greater awareness and understanding of symptoms.

The most prevalent disease in this study was hypertension, followed by back pain, arthritis/rheumatism/arthrosis, and depression/anxiety. In Brazil, data from PNAD 2003 showed that the most frequent diseases among people 18 years of age and over were back-pain, hypertension, arthritis, depression, asthma, and heart diseases (1). In the city of São Paulo, results from the Health, Wellbeing and Aging (SABE) study also revealed that hypertension was the most prevalent disease, followed by arthritis/ arthrosis/rheumatism (24). Other studies carried out in Brazil and in other countries showed that these are generally among the most frequent diseases $(1,22)$.

This study detected that stroke, osteoporosis, and depression/anxiety were the conditions that most frequently affect quality of life among the elderly. Individuals with stroke had severely affected, particularly in the role-physical, physical functioning, and general health scales. This finding is similar to what was described by Dorman et al. in a study on 2253 patients with cerebrovascular disease, for which the worst mean values were for physical functioning, role-physical, and role-emotional (25). In the present study, the low roleemotional score was also impressive (-21.6 points) (Table 3). The physical functioning scale, which measures the capacity of patients to perform basic activities of daily living, was severely diminished by stroke. Another scale that was very negatively effected was role-physical, which assesses work performance as a consequence of physical health. These impairments have a negative effect on autonomy and independence and make caregivers necessary. Thus, there is a need for public policies and the reorganization of health care services to provide improved living conditions for the elderly. There is also a need for programs offering support to caregivers. 
TABLE 2b. Mean scores and mean differences of SF- $36^{\circledR}$ scales according to the presence or absence of chronic conditions among 1958 elderly individuals in the State of São Paulo, Brazil, 2001-2002

\begin{tabular}{|c|c|c|c|c|}
\hline \multirow[b]{2}{*}{ Scale } & \multicolumn{2}{|c|}{ Mean SF- $36^{\circledR}$ scores and $95 \% \mathrm{Cl}$} & \multicolumn{2}{|c|}{ Mean differences } \\
\hline & $\begin{array}{c}\text { With } \\
\text { morbidity }\end{array}$ & $\begin{array}{l}\text { Without } \\
\text { morbidity }\end{array}$ & $\begin{array}{c}\text { Unadjusted } \\
(P \text { value })\end{array}$ & $\begin{array}{l}\text { Adjusted by } \\
\text { age and gender } \\
(P \text { value })\end{array}$ \\
\hline \multicolumn{5}{|l|}{ Osteoporosis } \\
\hline Physical functioning & $60.2(55.3-64.1)$ & $73.9(70.6-76.2)$ & $-13.7(0.000)$ & $-9.2(0.000)$ \\
\hline Role-physical & 70.9 (63.7-78.2) & $82.9(79.3-86.6)$ & $-12.0(0.001)$ & $-10.6(0.004)$ \\
\hline Bodily pain & $59.4(58.7-68.0)$ & $76.2(73.8-78.5)$ & $-16.8(0.000)$ & $-10.9(0.000)$ \\
\hline General health & $62.2(57.7-66.5)$ & $71.4(69.6-73.2)$ & $-9.2(0.000)$ & $-7.2(0.003)$ \\
\hline Vitality & $56.9(57.7-66.5)$ & $65.7(63.5-67.9)$ & $-8.8(0.000)$ & $-5.8(0.020)$ \\
\hline Role-emotional & $79.2(72.9-85.6)$ & $87.4(85.1-89.7)$ & $-8.2(0.014)$ & $-5.5(0.102)$ \\
\hline Social functioning & $82.0(77.0-86.9)$ & $86.7(84.2-89.3)$ & $-4.7(0.037)$ & $-3.2(0.209)$ \\
\hline Mental health & $64.1(59.6-68.4)$ & $71.0(69.3-72.7)$ & $-6.9(0.004)$ & $-5.2(0.030)$ \\
\hline \multicolumn{5}{|c|}{ Arthritis/rheumatism/arthrosis } \\
\hline Physical functioning & $62.5(58.9-66.1)$ & $74.8(74.8-77.4)$ & $-12.2(0.000)$ & $-10.1(0.000)$ \\
\hline Role-physical & $76.4(71.0-81.9)$ & $83.3(79.7-86.9)$ & $-6.9(0.007)$ & $-6.0(0.017)$ \\
\hline Bodily pain & $65.6(61.4-69.8)$ & $77.6(75.7-79.6)$ & $-12.0(0.000)$ & $-11.4(0.000)$ \\
\hline General health & $64.1(61.4-66.9)$ & $72.4(70.6-74.2)$ & $-8.2(0.000)$ & $-7.3(0.000)$ \\
\hline Vitality & $59.6(56.5-62.7)$ & $66.4(64.2-68.5)$ & $-6.7(0.000)$ & $-5.2(0.001)$ \\
\hline Role-emotional & $83.2(79.7-86.7)$ & $87.3(84.8-89.8)$ & $-4.1(0.006)$ & $-3.3(0.030)$ \\
\hline Social functioning & $84.2(80.0-88.5)$ & $87.1(84.4-89.9)$ & $-2.9(0.273)$ & $-1.6(0.555)$ \\
\hline Mental health & $66.7(64.6-68.8)$ & $71.2(69.3-73.2)$ & $-4.5(0.001)$ & $-3.7(0.008)$ \\
\hline \multicolumn{5}{|l|}{ Depression/anxiety } \\
\hline Physical functioning & $65.6(65.1-69.6)$ & $73.2(70.1-76.2)$ & $-7.6(0.002)$ & $-4.7(0.030)$ \\
\hline Role-physical & $76.8(71.4-82.3)$ & $82.5(78.1-86.9)$ & $-5.6(0.091)$ & $-4.7(0.154)$ \\
\hline Bodily pain & $68.5(65.1-71.9)$ & $76.0(73.4-78.6)$ & $-7.4(0.000)$ & $-6.7(0.001)$ \\
\hline General health & $62.1(58.5-65.7)$ & $72.6(70.7-74.5)$ & $-10.5(0.000)$ & $-9.7(0.000)$ \\
\hline Vitality & $55.8(52.8-58.8)$ & $67.1(64.5-69.6)$ & $-11.2(0.000)$ & $-9.8(0.000)$ \\
\hline Role-emotional & $78.5(74.1-82.8)$ & $88.3(85.5-91.1)$ & $-9.8(0.000)$ & $-9.2(0.000)$ \\
\hline Social functioning & $72.9(66.9-79.0)$ & $90.3(88.1-92.5)$ & $-17.3(0.000)$ & $-16.3(0.000)$ \\
\hline Mental health & $56.1(53.3-58.9)$ & $74.2(72.4-76.0)$ & $-18.1(0.000)$ & $-17.8(0.000)$ \\
\hline
\end{tabular}

Osteoporosis has a considerable effect on quality of life, particularly in the scales bodily pain, role-physical, and physical functioning. For musculoskeletal illness, Wee et al. found the greatest reductions were in the bodily pain, general health, and physical functioning scales (23). In Brazil, Lemos et al. studied 40 elderly women with diagnosed osteoporosis and found the lowest mean for SF-36 ${ }^{\circledR}$ values in the role-physical and role-emotional scales (19). In the present study, role-emotional was not among the most affected. Indeed, the mean values were higher than those of Lemos et al. This may be due to the fact that the present study was performed on a populationbased sample, while the Lemos study was carried out among patients in hospitals or outpatient services. Osteoporosis is a risk factor for bone fractures, the main cause of morbidity and mortality due to musculoskeletal diseases. Vertebral fractures are common with this condition and may cause bodily pain, incapacity, and disabilities (26). Mental, social, and emotional aspects among elderly people may also be affected by this disease due to insecurity, fear of falling, and consequently, decreased mobility and increased social impairment (19). Whereas diabetes and hypertension may go underreported due to a lack of awareness, when reported, it generally has a prior medical diagnosis. However, the population's awareness and understanding of osteoporosis, is more limited and therefore, there is less clarity around musculoskeletal pathologies. In the present study, among individuals reporting osteoporosis, 55.7\% also reported arthritis/rheumatism/arthrosis and $54.7 \%$ reported back-pain, compared to $21.1 \%$ and $27.9 \%$, respectively, among elderly without osteoporosis. These results indicate the possibility of confusion when reporting these diagnoses.

As expected, elderly individuals who reported depression/anxiety presented HRQOL that was affected by mental health and role-emotional. The damaging effect of mental status was profound, and the fact that mental condition significantly affects bodily pain was noteworthy as well (difference of -18.6 points in the mean score). The same finding was reported by Goldney et al. in a population-based study in Australia that found a difference of -15.8 points in the bodily pain scale among individuals who reported depression (21). Adequate care of elderly patients with depression or anxiety can help reduce suffering as well as the impact on quality of life. However, health care services in Brazil, and Latin

TABLE 3. Mean differences ${ }^{\mathrm{a}}$ in SF- $36^{\circledR}$ scores between elderly people with a specific disease, and those without any chronic condition, São Paulo, Brazil, 2001-2002 ( $p<0.001$ unless otherwise noted)

\begin{tabular}{|c|c|c|c|c|c|c|c|c|}
\hline Chronic condition & $\begin{array}{c}\text { Physical } \\
\text { functioning }\end{array}$ & $\begin{array}{l}\text { Role- } \\
\text { physical }\end{array}$ & $\begin{array}{l}\text { Bodily } \\
\text { pain }\end{array}$ & $\begin{array}{l}\text { General } \\
\text { health }\end{array}$ & Vitality & $\begin{array}{c}\text { Social } \\
\text { functioning }\end{array}$ & $\begin{array}{c}\text { Role- } \\
\text { emotional }\end{array}$ & $\begin{array}{l}\text { Mental } \\
\text { health }\end{array}$ \\
\hline Hypertension & -12.8 & -12.6 & -16.0 & -12.1 & -14.2 & $-9.4^{b}$ & $-6.8^{\mathrm{b}}$ & -11.2 \\
\hline Diabetes mellitus & -15.1 & $-11.8^{b}$ & -16.5 & -17.5 & -15.0 & -12.2 & $-8.8^{b}$ & -13.7 \\
\hline Back pain & -15.0 & -16.7 & -23.6 & -15.7 & -15.7 & $-11.6^{b}$ & $-7.0^{\mathrm{b}}$ & -11.0 \\
\hline Stroke & -30.3 & -34.3 & -22.0 & -24.1 & -17.3 & $-16.1^{\mathrm{b}}$ & $-21.0^{b}$ & -19.8 \\
\hline Osteoporosis & -20.0 & -21.3 & -25.4 & -16.8 & -17.8 & -14.5 & -14.4 & -14.9 \\
\hline Arthritis/rheumatism/arthrosis & -17.1 & -15.6 & -22.2 & -15.4 & -15.3 & -11.2 & $-8.5^{b}$ & -12.0 \\
\hline Depression/anxiety & -12.5 & -13.8 & -18.6 & -17.2 & -18.6 & -15.3 & -19.9 & -23.2 \\
\hline
\end{tabular}

${ }^{a}$ Beta coefficients, resulted from multiple linear regression analyzes. The variables included in the models were: a specific disease, age group, gender, and schooling.

${ }^{b} 0.001 \leq P<0.05$. 
TABLE 4. Unadjusted and adjusted SF- $36^{\circledR}$ mean scores of elderly individuals without any disease and mean differences according to the number of reported chronic conditions. ISA-SP, São Paulo, Brazil, 2001-2002

\begin{tabular}{lccccc}
\hline & Mean scores & \multicolumn{4}{c}{ Number of morbidities } \\
\cline { 5 - 6 } SF-36 ${ }^{\circledR}$ scales & No morbidity & & 2 & 3 or 4 & 5 or more \\
\cline { 5 - 6 } Unadjusted differences & & & & & \\
Physical functioning & 83.1 & -3.1 & $-9.0^{\mathrm{b}}$ & $-17.2^{\mathrm{c}}$ & $-25.6^{\mathrm{c}}$ \\
Role-physical & 92.8 & -5.1 & $-10.8^{\mathrm{b}}$ & $-14.7^{\mathrm{c}}$ & $-24.5^{\mathrm{c}}$ \\
Bodily pain & 87.7 & -3.6 & $-11.9^{\mathrm{c}}$ & $-19.3^{\mathrm{c}}$ & $-28.3^{\mathrm{c}}$ \\
General health & 81.3 & $-3.1^{\mathrm{b}}$ & $-8.3^{\mathrm{c}}$ & $-15.9^{\mathrm{c}}$ & $-25.4^{\mathrm{c}}$ \\
Vitality & 77.1 & $-4.3^{\mathrm{b}}$ & $-11.2^{\mathrm{c}}$ & $-18.4^{\mathrm{c}}$ & $-23.4^{\mathrm{c}}$ \\
Social functioning & 93.3 & -2.6 & $-5.3^{\mathrm{b}}$ & $-10.0^{\mathrm{b}}$ & $-16.8^{\mathrm{c}}$ \\
Role-emotional & 93.4 & 1.9 & $-4.1^{\mathrm{b}}$ & $-11.3^{\mathrm{b}}$ & $-22.4^{\mathrm{c}}$ \\
Mental health & 79.6 & -2.2 & $-8.4^{\mathrm{c}}$ & $-13.6^{\mathrm{c}}$ & $-21.6^{\mathrm{c}}$ \\
Adjusted differences & & & & & \\
by gender and age & & & & & \\
Physical functioning & 84.4 & -2.9 & $-7.1^{\mathrm{b}}$ & $-14.5^{\mathrm{c}}$ & $-22.0^{\mathrm{c}}$ \\
Role-physical & 87.3 & -4.8 & $-9.7^{\mathrm{b}}$ & $-13.5^{\mathrm{c}}$ & $-23.2^{\mathrm{c}}$ \\
Bodily pain & 85.4 & -4.5 & $-12.0^{\mathrm{c}}$ & $-19.3^{\mathrm{c}}$ & $-28.1^{\mathrm{c}}$ \\
General health & 79.5 & -2.6 & $-7.4^{\mathrm{c}}$ & $-14.9^{\mathrm{c}}$ & $-24.1^{\mathrm{c}}$ \\
Vitality & 76.6 & -3.4 & $-11.2^{\mathrm{c}}$ & $-16.4^{\mathrm{c}}$ & $-20.9^{\mathrm{c}}$ \\
Social functioning & 93.3 & $-4.0^{\mathrm{b}}$ & $-6.2^{\mathrm{b}}$ & $-10.6^{\mathrm{c}}$ & $-17.3^{\mathrm{c}}$ \\
Role-emotional & 92.4 & 2.8 & -2.5 & $-9.4^{\mathrm{b}}$ & $-20.0^{\mathrm{c}}$ \\
Mental health & 78.5 & -2.3 & $-8.2^{\mathrm{c}}$ & $-13.0^{\mathrm{c}}$ & $-20.9^{\mathrm{c}}$ \\
\hline
\end{tabular}

a Beta coefficients resulted from simple linear regression models.

${ }^{\mathrm{b}} 0.001 \leq P<0.05$.

${ }^{c} P<0.001$.

${ }^{\mathrm{d}}$ Beta coefficients resulted from multiple linear regression models including the number of chronic conditions, age, gender, and schooling.

America in general, are not yet structured or prepared to fulfill this demand with quality $(24,27)$.

Elderly individuals with diabetes also achieved lower quality of life scores, particularly on the general health scale. Other studies have also shown that general health was one of the most affected scales among patients with diabetes (21-23).

The HRQOL of elderly people suffering from hypertension was most evident on the vitality and bodily pain scales. Erickson et al. also found that among individuals with hypertension, the greatest losses were in the areas of role-physical and general health (20), while Wang et al. reported the largest differences in rolephysical and vitality (28). Wee et al. found that hypertension and diabetes had less of an influence on HRQOL than musculoskeletal diseases or heart disease (23). The results from the SABE study (29) reveal that individuals with hypertension have a $39 \%$ greater chance of being dependent with regard to activities of daily living, whereas this figure increases to $82 \%$ in those with heart disease and 59\% in those with joint diseases; no association was observed in diabetic patients. Concurring with these findings, the pre- sent study found that hypertension and diabetes had less of an influence on HRQOL than did the other diseases studied. This may be explained by the fact that there are more structured programs for the follow up of these diseases, thereby facilitating early diagnosis before the illnesses have caused greater consequences. Hypertension can have a long, asymptomatic progression, with no great impact on the quality of life of patients. Studies have also shown a greater use of medication by patients with diabetes and hypertension, which indicates greater access to services for these diseases in comparison to other illnesses (1, 27). Nonetheless, it is important to stress that the prevalence of hypertension is very high and its impact on HRQOL affects a large number of people.

Diabetes and hypertension were found to negatively affect the general health and vitality scales, which include areas such as energy, fatigue, and self-perception of health. This suggests that these diseases may have a negative effect on an individual's perception of health as well as on his/her perception of will and energy level. Special care regarding the improvement of these aspects is important in health care services offered to elderly individuals with these pathologies.

Arthritis/rheumatism/arthrosis and back-pain had considerable negative effects on the bodily pain scale. Another Brazilian population-based study also found this area to be the most affected among patients with arthritis (30). Ciconelli et al. found lower scores for rolephysical and bodily pain among 50 patients with rheumatoid arthritis, with a mean age of 49 years (11). Other studies have also described considerable effects on bodily pain among people with musculoskeletal diseases $(17,23)$. This scale has proven to be one of the most affected by several chronic diseases. This highlights the importance of studies and interventions on pain management among elderly individuals, especially since chronic pain may lead to severe depression and incapacity (31).

The present study also showed that HRQOL decreased as the number of morbidities increased. Using data from the World Health Survey in Brazil, Theme-Filha et al. found that the presence of chronic disease increased the perception of poor health by a factor of 2.7 (32). In our study, the presence of two or more diseases had a substantial negative effect on HRQOL scales.

The role-emotional and social functioning scales were the ones least affected in the presence of the chronic conditions studied here. A study carried out by Alonso et al. that employed the SF- $36^{\circledR}$ in eight countries, found mental health and social functioning to be the least affected in relation to the eight diseases investigated (22). The same was reported by Wee et al. in a study carried out in Singapore (23). The relatively low impact of these diseases on role-emotional and social functioning may be explained by adapting to the conditions of the disease and/or adopting new lifestyle behaviors. There is also the possibility of the patients being able to count on some form of support from family and society $(33,34)$.

One of the limitations of the present study was that it used self-reported information on chronic diseases. The accuracy of such information differs according to the type of disease; the severity of symptoms; and the demographic, cultural, socioeconomic, emotional, and other characteristics of the interviewees (1). There is greater agreement between self-reported diseases and those logged in medical files when the condition 
causes incapacities and requires followup (35). The validity of the information is greater when the study is conducted by means of face-to-face interviews (36). Self-reported information on diseases such as diabetes, hypertension, and stroke has greater validity than that of other conditions, such as heart failure, obstructive lung disease, and gastrointestinal ulcer (1). Reported morbidity is a frequently-used type of information in population surveys and, despite some limitations, a number of studies have shown its validity $(3,37,38)$. Another limitation of our study is that no inference regarding causality could be made because the design was cross-sectional.

The importance of the present study comes from the fact that it is the first Brazilian population-based report to quantify the impact of several diseases, as well the impact of the number of chronic conditions, on the eight areas assessed by SF- $36^{\circledR}$. The results were similar to those obtained in other countries, and there is general agreement regarding the most affected areas. This suggests the validity of the SF- $36^{\circledR}$ for population-based research in Brazil.

The differing impact of diseases on the different HRQOL scales indicates aspects that should receive better consideration in health care programs for the elderly, such as the negative impact on the vitality and general health scales, which indicate fatigue, lack of energy, and negative feelings on the part of elderly patients. The World Health Organization proposal for "active aging" stresses the importance of promoting mental health and strengthening social relationships and support, as well as the active participation of the elderly in the community so as to maintain or improve quality of life (39).

The present findings stress the need for better organization of and quality in health care services for the chronic conditions of the elderly; such improvements would help avoid the complications of these diseases and the accumulation of comorbidities. Health care services must become more effective in managing the chronic pain that accompanies various diseases. Pain is very much present in the lives of the elderly (even in cases of emotional problems) and has a markedly negative effect on autonomy and wellbeing. The high prevalence of chronic diseases that accompany the aging process requires advances and adjustments in prevention, control, and treatment procedures.

In addition to adequate medical care for elderly patients, action by the health care services is fundamental to changing life habits and promoting healthy behav- iors that can postpone the onset of chronic disease and help to control any illness that is already present. In these health promotion actions, it is imperative to offset health disparities by giving special attention to the elderly of lower socioeconomic status (39).

The results from the present study point to the need for interventions that consider the impact of disease on the different dimensions of health-related quality of life, with special attention to elderly people with comorbidities. The impact of disease on HRQOL scales should be periodically measured to evaluate the improvements made in health care and social services for the elderly.

Acknowledgements. The authors are grateful to the Research Support Foundation of the State of São Paulo (FAPESP) Public Policy Project, process no 88/14099 and the São Paulo State Secretary of Health for financing the fieldwork; to the Secretary of Health Surveillance of the Ministry of Health for financial support in the data analysis through the Health Analysis Collaborative Center of FCM/UNICAMP (partnership 2763/2003); and to the Secretary of Education of the State of Minas Gerais for the permission granted to the first author to attend the Master's course.

\section{REFERENCES}

1. Barros MBA, César CLG, Carandina L, Torre GD. Desigualdades sociais na prevalência de doenças crônicas no Brasil, PNAD-2003. Ciênc e Saúde Coletiva 2006;11(4):911-26.

2. Lima-Costa MF, Loyola Filho AI, Matos DL. Tendências nas condições de saúde e uso de serviços de saúde entre idosos brasileiros: um estudo baseado na Pesquisa Nacional por Amostra de Domicílios $(1998,2003)$. Cad. Saúde Pública 2007;23(10):2467-78.

3. Almeida MF, Barata RB, Montero CV, Silva ZP. Prevalência de doenças crônicas autoreferidas e utilização dos serviços de saúde, PNAD/1998, Brasil. Ciênc e Saúde Coletiva 2002;7(4):743-56.

4. Ramos LR. Fatores determinantes do envelhecimento saudável em idosos residentes em centro urbano. Projeto Epidoso, São Paulo. Cad Saúde Pública 2003;19(3):793-8.

5. Brasil. Ministério da Saúde. Portaria no 2.528 de 19 de outubro de 2006. Política Nacional de Saúde da Pessoa Idosa. Accessed on: 30 November 2007. Available at http://dtr2001. saude.gov.br/sas/PORTARIAS/Port2006/ GM/GM-2528.htm

6. Lima-Costa MF, Veras R. Saúde Pública e Envelhecimento [Editorial]. Cad. Saúde Pública 2003;19(3):700-1.
7. Brasil. Ministério da Saúde 2006b. Secretaria de Vigilância em Saúde. Política Nacional de promoção da Saúde/Ministério da Saúde, Secretaria de Atenção à Saúde. Brasília: Ministério da Saúde; 2006.

8. Centers for Disease Control and Prevention. Measuring Health Days. Atlanta, Georgia: CDC; 2000 .

9. Seidl EMF, Zannon CMLC. Qualidade de vida e saúde: aspectos conceituais e metodológicos. Cad. Saúde Pública 2004; 20(2): 580-8.

10. McDowell I, Newell C. Measuring health: a guide to rating scales and questionnaires. 2nd ed. New York: Oxford University Press, Inc.; 1996:447-56.

11. Ciconelli RM, Ferraz MB, Santos W, Meinão I, Quaresma MR. Tradução para a língua portuguesa e validação do questionário genérico de avaliação de qualidade de vida SF-36 ${ }^{\circledR}$ (Brasil SF-36 ${ }^{\circledR}$ ). Rev Bras Reumatol 1999;39(3):143-50.

12. Ware JE, Gandek B. Overview of the SF-36 ${ }^{\circledR}$ Health Survey and international quality of life assessment (IQOLA) project. J Clin Epidemiol 1998;51(11):903-12.

13. César CLG, Carandina L, Alves MCGP, Barros MBA, Goldbaum M. Saúde e condição de vida em São Paulo. Inquérito multicêntrico de saúde no Estado de São Paulo. ISA-SP. São Paulo: FSP/USP; 2005.

14. Alves MCGP. Plano de Amostragem. In: César CLG, Carandina L, Alves MCGP, Barros MBA, Goldbaum M. Saúde e condição de vida em São Paulo. Inquérito multicêntrico de saúde no Estado de São Paulo. ISA-SP. São Paulo:FSP/USP; 2005:47-62.

15. Silva NN. Amostragem Probabilística: um curso introdutório. São Paulo: Edusp; 2001.

16. Nogueira R, Franca M, Lobato MG, Belfort R, Souza CB, Gomes JAP. Qualidade de vida dos pacientes portadores de síndrome de Stevens-Jonnson. Arq Bras Oftalmol 2003;66: 67-70.

17. Falcão FCOS. Qualidade de vida e capacidade funcional em idosos com dor lombar crônica [dissertação]. Campinas: UNICAMP; 2006.

18. Fernandes MR, Carvalho LBC, Prado GF. A functional electric orthesis on the paretic leg improves quality of life of stroke patients. Arq Neuropsiquiatr 2006;64(1):20-3.

19. Lemos MCD, Miyamoto ST, Valim V, Natour J. Qualidade de vida em pacientes com osteoporose: correlação entre OPAQ e SF- $36^{\circledR}$. Rev Brás Reumatol 2006;46(5):323-8. 
20. Erickson SR, Willians BC, Gruppen LD. Perceived symptoms and health-related quality of life reported by uncomplicated hypertensive patients compared to normal controls. J Human Hypertension 2001;15:539-48.

21. Goldney RD, Pjillips PJ, Fisher LJ, Wilson DH. Diabetes, depression and quality of life. Diabetes Care 2004;27(5):1066-70.

22. Alonso J, Ferrer M, Gandek B, Ware Jr JE, Aaronson NK, Mosconi P et al. Health-related quality of life associated with chronic conditions in eight countries: Results from the International Quality of Life Assessment (IQOLA) Project. Qual Life Res 2004;13: 283-98.

23. Wee H-L, Cheung Y-B, Li S-C, Fong K-Y, Thumboo J. The impact of diabetes mellitus and other chronic medical conditions on health-related quality of life: is the whole greater than the sum of its parts? Health and quality of life outcomes 2005:3-12.

24. Lebrão ML, Laurenti R. Saúde, bem-estar e envelhecimento: o estudo SABE no município de São Paulo. Rev Bras Epidemiol 2005; 8(2):127-41.

25. Dorman PJ, Dennis M, Sandercock P. How do scores on the EuroQol relate to scores on the SF-36 ${ }^{\circledR}$ after stroke? Stroke 1999;30:2146-51.

26. Bandeira F, Maia AC, Canuto V, Freese E. Osteoporose: características epidemiológicas e biológicas. In: Freese E. Epidemiologia, políticas e determinantes das doenças crônicas não transmissíveis no Brasil. Recife: Ed. Universitária da UFPE, 2006:177-6.
27. Organização Pan-Americana da Saúde. Saúde nas Américas: 2007. Washington, D.C.: OPAS; 2007. (Scientific Publication No. 662)

28. Wang W, Lopez V, Ying CS, Thompson DR. The psychometric properties of the Chinese version of the SF- $36^{\circledR}$ health survey in patients with myocardial infarction in mainland China. Qual Life Res 2006;15:1525-31.

29. Alves L, Leimann BCQ, Vasconcelos MEL, Carvalho MS, Vasconcelos AGG ET al. A influência das doenças crônicas na capacidade funcional dos idosos do Município de São Paulo, Brasil. Cad Saúde Pública 2007;23(8): 1924-30.

30. Senna, ER. Estudo sobre a prevalência de doenças reumáticas na cidade de Montes Claros. [thesis]. São Paulo: UNIFESP; 2002.

31. Dellarozza MSG, Pimenta CAM, Matsuo T. Prevalência e caracterização da dor crônica em idosos não institucionalizados. Cad Saúde Pública 2007;23(5):1151-60.

32. Theme-Filha MM, Szwarcwald CL, SouzaJínior PRB. Socio-demographic characteristics, treatment coverage, and self-rated health of individuals who reported six chronic disease in Brasil, 2003. Cad Saúde Pública 2005 21: S43-53.

33. Schlenk EA, Erlen JÁ, Dunbar-Jacob J, McDowell L, Enberg S, Sereika SM et al. Healthrelated quality of life in chronic disorders: a comparison across studies using the MOS SF-36 ${ }^{\circledR}$. Qual Life Res 1998;7:57-65.

34. Jönson A-C, Lindgren I, Hallström B, Norrving B, Lindgren A. Determinants of quality of life in stroke survivors and their informal caregivers. Stroke 2005;36:803-8.

35. Ferraro KF, Su YP. Physician-evaluated and self-reported morbidity for predicting disability. Am J Public Health 2000;90(1):103-8.

36. Bergmann MM, Jacobs ET, Hoffmann K, Boeing $\mathrm{H}$. Agreement of self-reported medical history: comparison of an in-person interview with a self-administered questionnaire. Eur J Epidemiol 2004;19(5):411-6.

37. Wu SC, Li CY, Ke DS. The agreement between self-reporting and clinical diagnosis for selected medical conditions among the elderly in Taiwan. Public Health 2000;114: 137-42.

38. Knight M, Stewart-Brown S, Fletcher L. Estimating health needs: the impact of a checklist of conditions and quality of life measurements on health information derived from community surveys. J Public Health Med 2001;233(3):179-86.

39. Organização Pan-Americana da Saúde. Envelhecimento ativo: uma política de saúde. Brasília: Organização Pan-Americana da Saúde; 2005.

Manuscript received on 16 March 2008. Revised version accepted for publication on 26 September 2008.
RESUMEN

\section{Impacto de las enfermedades crónicas en la calidad de vida de los adultos mayores en el estado de São Paulo, Brasil: estudio poblacional}

Palabras clave Salud del anciano, enfermedad crónica, calidad de vida, Brasil.
Objetivos. Determinar el impacto de las enfermedades crónicas y el número de enfermedades en los diversos aspectos de la calidad de vida relacionada con la salud (HRQOL) en adultos mayores de São Paulo, Brasil.

Métodos. Se empleó la encuesta de salud SF- $36^{\circledR}$ para evaluar el impacto de las enfermedades crónicas de mayor prevalencia sobre la HRQOL. Se realizó un estudio poblacional transversal con un muestreo por conglomerados estratificado en dos etapas. Se obtuvieron los datos de una encuesta multicéntrica sobre la salud aplicada mediante entrevistas en hogares de varios municipios del estado de São Paulo. Se evaluaron siete enfermedades - artritis, dolor de espalda, depresión/ansiedad, diabetes, hipertensión arterial, osteoporosis y accidentes cerebrovasculares- y sus efectos sobre la calidad de vida.

Resultados. De los 1958 adultos mayores de 60 años o más, 13,6\% informaron no padecer ninguna de las enfermedades, mientras $45,7 \%$ presentaron tres enfermedades crónicas o más. La presencia de cualquiera de las siete enfermedades crónicas estudiadas influyó significativamente en la puntuación de casi todas las escalas de la SF$36^{\circledR}$. La HRQOL alcanzó valores inferiores cuando la persona tenía depresión/ansiedad, osteoporosis o había sufrido un accidente cerebrovascular. A mayor número de enfermedades, mayores eran los efectos negativos en las dimensiones de la SF-36 ${ }^{\circledR}$. La presencia de tres enfermedades o más afectó significativamente la HRQOL en todas las áreas. Las escalas más afectadas por las enfermedades fueron dolor físico, salud general y vitalidad.

Conclusiones. Se encontró una alta prevalencia de enfermedades crónicas en la población de adultos mayores; la magnitud del efecto sobre la HRQOL dependió del tipo de enfermedad. Estos resultados destacan la importancia de prevenir y controlar las enfermedades crónicas para reducir la comorbilidad y disminuir su impacto sobre la HRQOL en los adultos mayores. 